\title{
INTEGRASI SAINS DAN AGAMA DALAM PERSPEKTIF ETIKA
}

\section{Ahmad Kholil}

Fakultas Humaniora dan Budaya Universitas Islam Negeri Malang Junusan Bahasa dan sastra Arab. Jl. Gajayana 50. Malang 65144 Telp.0341-551354,081807765237. e-mail: Khumi_01@ yahoo.com

\section{Abstract}

The dichotomy between religion and non-religion knowledge has existed in the Islamic classical thought. However, dichotomy has not impacted much on the intellectual matters. In the perception of classical ulama both of the knowledge was considered important, therefore, both were necessary to be mastered. The pioneered ulama on the science and deeds recognized the validity and scientific position of each group. It is different from the western modern sciences that often denied and downgraded the religious knowledge. However, the western science perception influenced Moslem society through imperialism. It emerged a strict dichotomy between religion knowledge taught in the (traditional) Islamic education and the (secular) non-religion knowledge taught in general education institutions. The Islamic knowledge perspective has viewed that natural phenomena do not happen without any relation with Ilahi's power as the phenomena are not more than the God's creative area. Therefore, learning the non-religious knowledge and understanding closely God's creation system is significant.

Key words: science, philosophy, Islam, ethics 


\section{Pendahuluan}

"Sejarah telah membuktikan bahwa pemisahan sains dari keimanan menyebabkan kerusakan yang sulit diperbaiki lagi. Keimanan mesti dikenali lewat sains, keimanan bisa tetap aman dari berbagai takhayul melalui pencerahan sains. Keimanan tanpa sains akan menimbulkan fanatisme dan kejumudan. Jika saja tidak ada sains dan ilmu, agama dalam diri para penganutnya akan menjadi instrumen di tangan para dukun yang cerdik" (Muthahhari, 2007: 88).

"Ilmu pengetahuan hanya dapat diciptakan oleh mereka yang dipenuhi dengan gairah untuk mencapai kebenaran dan pemahaman. Tetapi sumber perasaan itu berasal dari tataran agama, termasuk di dalamnya adalah keimanan. Ada kemungkian bahwa semua sistem atau peraturan yang ada di dunia wujud itu bersifat rasional, dapat dipahami oleh akal" (Rahmat, 2005: 53).

Dalam budaya masyarakat muslim, orang akan :dianggap menjadi kafir kalau sampai memungkiri bahwa al Quran adalah ayat Allah yang merupakan sumber ilmu dan hukumNya. Sebagai sumber ilmu dan hukum dari yang Mahabenar, al Quran selalu berbicara mengenai kebenaran yang diperuntukkan bagi kemaslahatan hambaNya. Namun, sebagai makhiuk yang dikaruniai akal, di mana dengannya manusia adalah ciptaanNya yang paling agung dan mulia, beberapa orang masih sering meragukan bahwa fenomena alam yang dapat diamati secara langsung dengan menggunakan alat atau tanpa alat juga merupakan tanda-tanda atau ayat-ayat kebenaran $N y a$ juga.

Al Quran sering dijadikan legitimasi untuk menegaskan hal-hal tertentu dalam kualifikasi islami atau tidak. Artinya, ketika sesuatu sesuai dengan bunyi literal dengan apa yang ada dalam al Quran, dengan serta merta dinyatakannya sebagai yang baik dan islami. Sebaliknya, jika tidak sesuai dengan bunyi literalnya berarti tidak islami. Demikian juga, sering ditemukan ajakan dan dakwah kepada Islam hanya dengan menyuguhkan ayat-ayat Qurani demi menunjukkan bahwa Islam itu baik. Naifnya, ajakan kepada kebaikan itu dilakukan dengan cara pemaksaan, yang sudah jelas bertentangan dengan seruan al Quran sendiri.

Sebenarnya, al Quran dan fenomena alam sama-sama sebagai ayat- 
ayat Allah. Yang pertama disebut ayat-ayat tadwini dan yang kedua ayat-ayat kawni. Sebagai ayat-ayatNya, keduanya senantiasa benar dan juga berbicara mengenai kebenaran. Pertama dijadikan landasan utama para tokoh ilm al naql dan yang kedua menjadi objek pengamatan para ilmuwan atau saintifik. Kebenaran yang terkandung dalam ayat tadwini didapat dari kemacangan ilmu bahasa dengan metode tafsir atau ta' wil, sedangkan kebenaran yang terkandung dalam ayat kawni didapat dari pengamatan ilmiah atau penelitian (tajribi). Sifat kebenaran dari keduanya selalu debatable karena memang tidak semua orang mampu menafsir dan menta'wil, seperti juga tidak semua orang mampu mengamati dan meneliti gejala-gejala alam sampai detil.

Tulisan ini akan mengungkap dan mendiskusikan masalah ilmu dän agama Islam yang menjadi pijakan untuk mendapatkan kekayaan duniawi dan ukhrawi, kekayaan akal dan batin. Tulisan ini terlahir dari keinginan yang besar dalam diri penulis untuk bertanya kepada siapa saja, bahkan kepada apa saja ketika mendengar istilah "Integrasi al Quran dan Saiñs" yang menjadi jargon kampus ini. Kutipan di atas kiranya sudah cukup memberi gambaran mengenai apa yang akan dibahas di sini. Penulis berusaha mengikat makna dengan kata, setelah bertanya dan membaca. Tentunya ada kandungan yang subyektif, tapi penulis tetap akan bertanggung jawab untuk hal tersebut.

Idealnya, manusia sebagai pelaku aktif dalam proses pencarian makna hidup harus mengikuti realitas nilai dari ilmu pengetahuan dan agama, yaitu hakikat atau kebenaran sesuai apa adanya. Namun pada kenyataannya, seringkali.manusia membawa ilmu pengetahuan dan agama semaunya, sesuai dengan keinginannya sendiri, untuk kepentingan tertentu, misalnya sosial, budaya, politik atau ekonomi. Sains dan agama adalah satu, sama-sama mencari kebenaran untuk manusia dan kedamaian dunia. Kebenaran agama ada pada wahyu, dipahami lewat tafsir dan ta'wil lalu diamalkan. Sedangkan kebenaran sains ada pada realitas ilmiah lewat hipotesa yang logis dan rasional atau penelitian (tajribah). Agama bukan untuk Tuhan, tapi untuk manusia. Demikian halnya sains, untuk manusia juga. Inilah inti dari Sabda purba, ketika 
Tuhan masih sendirian sebelum diciptakannya alam, 'Kalau bukan karenamu (Muhammad) Aku tidak menciptakan alam seisinya'.

\section{Makna Agama}

Meskipun di Indonesia hanya ada beberapa agama yang diakui, sebenarnya di dunia ini ada banyak agama, hingga pada kelompok atau sekte yang tidak mencerminkan nilai agama sekalipun ada yang menyebutnya, atau setidaknya diakui oleh penganutnya sebagai agama (Agus, 2007: 315). Agama selalu diterima dan dialami secara subyektif, karena itu, untuk mendefinisikannya seringkali disesuaikan dengan pengalaman dan penghayatan para pelakunya sendiri. Salah satu definisi misalnya yang dikemukakan oleh Mukti Ali, "Agama adalah percaya akan adanya Tuhan Yang Esa dan hukum-hukum yang diwahyukan kepada kepercayaan utusanutusannya untuk kebahagiaan hidup manusia di dunia dan di akhirat" (Muchtar, 2001: 10).

Definisi yang diutarakan Mukti Ali di atas jelas sekali mengacu kepada pengamatan dan pengalamannya sendiri, dan definisi tersebut tidak merangkum pengertian secara luas mengenai agama. Ia sedang mendefinisikan agama seperti yang dilihat, diamati dan dirasakan dalam Islam. Keesaan seperti yang diyakini muslim atau penganut monoteistik lainnya tidak selalu ada pada pengertian yang sama. Misalnya pada agamaagama besar, ternyata tidak semua meyakini Tuhan Yang Maha Esa, seperti Hindu yang meyakini banyak Dewa dan Kristen yang percaya pada Trinitas jelas tidak bisa masuk dalam definisi seperti yang dikatakan Mukti Ali.

Dalam The Encyclopedia of Phylosophy pada entri Religion ada beberapa definisi agama, di antaranya sebagai berikut (Rahmat, 2005: 50-51):

"Agama adalah kepercayaan kepada Tuhan yang selalu hidup, yakni kepada jiwa dan kehendak Ilahi yang mengatur alam semesta dan mempunyai hubungan moral dengan umat manusia." (James Martineau)

"Agama adalah pengakuan bahwa segala sesuatu adalah manifestasi dari Kuasa yang melampaui pengetahuan kita." (Herbert Spencer)

Ulul Albab, Vol. 10, No. 1, 2009 
"Agama adalah etika yang ditingkatkan, dinyalakan, dan diterangi oleh perasaan." (Mathew Arnold)

"Agama seseorang adalah ungkapan dari sikap akhirnya pada alam semesta, makna dan tujuan singkat dari seluruh kesadarannya pada segala sesuatu." (Edward Caird).

Seperti yang dicantumkan di atas, pembahasan mengenai agama berputar pada persoalan Tuhan dan ketuhanan, dan kata ini, oleh para pengamat keagamaan, agar bisa merangkum semua jenis kepercayaan masyarakat yang lazimnya disebut agama diganti dengan "Kuasa yang transenden", "Kuasa-kuasa di atas manusia", "Sesuatu yang di luar", "Realitas transenden" atau "Realitas supernatural". Pembahasan tentang Tuhan atau konsep-konseplain yang berhubungan dengan tema-tema keilahian biasanya disebut teologi. Namun demikian, tidak semua agama memiliki konsep yang disebut teologi.

Joseph Campbell dalam The Power of Myth menceritakan pembicaraan seorang filosof yang bertanya kepada seorang pendeta Shinto di Jepang:

"Kami telah menyaksikan banyak sekali upacara dan telah mengunjungi beberapa biara Anda. Akan tetapi, saya belum memahami ideologi Anda. Saya belum mendapatkan teologi Anda". Pendeta itu kemudian menjawab, "Kami memang tidak mempunyai teologi. Kami menari" (Campbell, pada pengantar buku The Power of Myth, 1988).

Para pengikutShinto, seperti dikatakan sang pendeta, memang tidak mau membicarakan Tuhan atau apa saja namanya yang berhubungan dengan Tuhan. Bagi mereka, semua tidak dapat digambarkan, tidak dapat diceritakan, dan tidak dapat diuraikan. Dengan kata lain, mereka tidak ingin membicarakan agama, mereka ingin mengaplikasikannya dalam kehidupan yang nyata dalam laku keseharian. Iniseperti Islam pada masa kehidupan Nabi dan sahabat, atau Islam seperti yang dilukiskan Iqbal dalam "The Reconstruction of Religious Thought in Islami" yang lebih mengutamakan amal daripada ide atau pemikiran ansich (Iqbal, 1981: 5).

Agama memang tidak bisa dilacak dari pengetahuan rasional saja, karena Tuhan sebagai penuntun kepada kebenaran yang diyakini oleh 
pemeluknya tidak dapat dibicarakan. Agama juga tidak bisa dilacak hanya dari tindakan moral, karena ia menuntut niat sebagai basis amal. Oleh karena itu, tidak sedikit ilmuwan yang mencoba melihatnya secara fenomenologis. Agama berasal dari perasaan kebergantungan mutlak kepada Yang Tak Terhingga (feeling of absolute dependenc kata Friederich Schleirmacher. Agama sebagai pengalaman pertemuan dengan Yang Menimbulkan rasa ngeri dan cinta, sebuah misteri yang menakutkan dan sekaligus mempesona, kata Rudolf Otto. Konsep ini, sebuah misteri yang menakutkan dan mempesona kemudian diberi pengertian baru oleh Mircea Eliade dengan konsep "yang sakral". the sacred. Bagi Eliade pada setiap kebudayaan selalu dikenal adanya "sense of.sacred", yang tercermin dalam ritus dan simbolnya. Inilah esensi dari ;agama. Wiston King dalam Encyclopedia of religion menulis:

Perumusan yang mutakhir dan paling berpengaruh berkenaan dengan kesakralan sebagai esensi pengalaman beragama dinyatakan oleh Mircea Eliade. Ia mengembangkan konsep sebelumnya. Yang sakral menurut Eliade tidak lagi dicari secara eksklusif pada jenis pengalaman berupa pertemuan -dengan Tuhan. la banyak ditemukan pada simbolisme dan ritual hampir semua budaya, terutama budaya Asia dan budaya primitif. la diwujudkan dalam ruang sakral, misalnya di tempat suci dan rumah ibadah, di daerahdaerah tabu, bahkan secara terbatas ada pada pendirian bangunan sesuai dengan perasaan axis mundi, orientasi pada pusat alam yang sejati atau sakral (Rahmat, 2005: 23).

Sementara itu, kalau diamati, apa yang Micea Eliade utarakan mengenai agama mirip dengan apa yang didefinisikan Emile Durkheim beberapa dekade sebelumnya. Dalam definisi Emile Durkheim, agama adalah "religion is unfied system of belief and practices relative to sacred things, that is to say, thing set apart and forbidden" (agama adalah suatu sistem kepercayaan dan praktik-praktik ritual yang dianggap suci, yaitu sesuatu yang terpisahpisah dan hal-hal yang terlarang) (Pals, 1996: 99). Pandangan Durkheim ini mengemukakan dua hal pokok dalam masalah agama, yaitu apa yang disebut kepercayaan dan apa yang disebut ritus. Yang pertama merupakan bentuk dari pikiran (ideas), merupakan keyakinan yang ada dalam hati dan yang kedua merupakan bentuk dari tindakan (actions), berupa aplikasi dari apa yang diyakini.

Ulul Albab, Vol. 10, No. 1, 2009 
Definisi mengenai agama memang selalu tidak komprehensif, bersifat satu sisi, parsial, dan tidak mencakup semuanya. Definisi tersebut sebenarnya hanya menangkap sebagian dari realitas agama yang teramat kompleks dan tak terbatas, sementara dengan definisi agama menjadi terbatasi. Dari beberapa definisi tersebut, Leuba dalam The Psychological Study of Religion, seperti yang dikatakan Jalaluluddin Rahmat membaginya dảlam tiga kategori (Rahmat, 2005: 26), yaitu sebagai berikut:

1. Intelektualistik (agama menegaskan kepercayaan);

2. Voluntaristik (agama menekankan kemauan); dan

3. Afektivistik (agama meliputi perasaan).

Dalam konteks sosial budaya, dengan melihat cara orang menjalankan ajaran agamanya, ada yang menganggap agama itu hanya menjadi urusan individual antara seseorang dengan Tuhannya. Ada juga yang menganggap bahwa agama sebenarnya adalah urusan politik yang terlibat di dalamnya semua anggota masyarakat. Ada juga yang menganggap bahwa agama hanyalah urusan ibadah dan pemujaan kepada Tuhan saja. Begitu sulitnya mendefinisikan agama, lebih-lebih dengan munculnya fenomena orang-orang yang berani menegaskan "I am spiritualist but not religious"' (penganut dan pengembang spiritual tapi bukan menganut suatu agama), hingga dapat disimpulkan bahwa di dunia ini sebenarnya tidak ada orang yang tidak beragama.

Sementara itu, Dean Hoge dalam laporan penelitiannya yang mengamati fenomena kehidupan sosial keagamaan membagi agama dalam lima entitas, yaitu preferensi agama, afiliasi keagamaan, keterlibatan keagamaan, keimanan agama, dan perilaku personal menurut agama. Sebagai contoh, keimanan agama dirumuskan sebagai kepercayaan kepada Tuhan atau ajaran Tuhan sebagaimana terdapat di dalam kitab-kitab suci dan ketergabungannya di dalam suatu komunitas atau organisasi keagamaan. Perilaku agama personal diukur dengan kegiatan, seperti sembahyang, membaca kitab suci, menelaah teks keagamaan, dan perilaku lain yang mendapat manfaat spiritual. Suatu perilaku yang diyakini membawa pada kebaikan atau kepada keadaan jiwa yang tenang dan bahagia (Rahmad. 2005: 32). Dalam kaitan agama sebagai 
kepercayaan kepada Tuhan atau apa saja yang merujuk kepadaNya seperti Yang Transenden, yang Sakral, yang Suci, yang Di Luar (the beyond), sahabat Ali (karroma Allah Wajhah) pernah ditanya salah seorang sahabatnya Zi'lab al-Yamani (Shihab, 1996: 27):

$$
\begin{aligned}
& \text { هل رأيت ريك ؟ قال وكيف أعبد مالا أراه ؟ قبل وكيف تراه ؟ بلاتراه }
\end{aligned}
$$

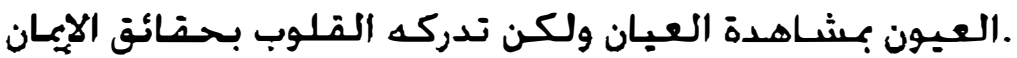

"Apakah anda pernah melihat Tuhan? Beliau menjawab, "Bagaimana saya menyembah sesuatu yang tidak saya lihat" Bagaimana anda melihat-Nya? Tanyanya kembali. Lalu beliau menjawab, "Dia tidak bisa dilihat dengan pandangan mata yang kasat, tatapi bisa dilihat dengan hati, dengan pandangan keimanan."

Melihat pengertian agama yang begitu luas, kiranya perlu dicukupkan di sini, sedangkan untuk menegaskan sikap keagamaan yang berkaitan dengan Islam yang secara lughawiberarti kepasrahan dan kedamaian, Nabi SAW pernah ditanya, "Apa itu agama?". Beliau menjawab, "Agama adalah etika", agama adalah yang bisa memberi pencerahan "nasihah". Pada bagian lain Nabi juga mengatakan tentang siapakah orang Islam itu. Jawaban Beliau "Orang yang mampu menyelamatkan orang lain (yang mendambakan kedamaian) dari gangguan lidah dan tangannya" (من سـلم المس لمهون من لسانه ويدم). Bentuk ini, merupakan konsekuensi berislam mengikuti ajaranNya dengan baik, seperti yang

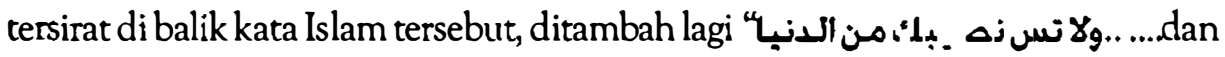
" أنتم أعلهم بأمور دنباكم" Berdasarkan hal tersebut, maka Islam sejati harus menjadi inspirator dari model kehidupan yang damai, penuh kerukunan, demokratis, dan membuka ruang yang luas bagi pengembangan sains dan teknologi.

\section{Integrasi Islam dan Sains}

Menurut Ian G. Barbour, ada empat tipologi hubungan antara agama dan sains. Pendapat Barbour ini dilontarkan mulanya pada tahun 1960 dan terus dipertahankan hingga terbit bukunya yang terbaru When Science Meets Religion yang diterjemahkan oleh Mizan dengan judul baru Juru Bicara Tuhan 2002. Keempat hubungan itu adalah konflik, independensi, dialog, dan integrasi. Dalam konflik, agama dan sains dipandang sebagai dua bidang yang berbeda dan saling berlawanan, sehingga orang dituntut memilih 
salah satu; menerima agama menolak sains atau sebaliknya. Pandangan independensi menyatakan bahwa agama dan sains adalah dua bidang yang berbeda, berbicara mengenai hal-hal yang berbeda dengan menggunakan metode dan bahasa yang berbeda pula. Pandangan ketiga, dialog, menegaskan bahwa ada titik persinggungan antara agama dan sains. Oleh karena itu, perlu diupayakan untuk melihat kemungkinan teori-teori ilmiah untuk menerangi kepercayaan-kepercayaan agama atau sebaliknya.

Adapun yang keempat, integrasi, dalam pandangan Barbour adalah suatu upaya untuk memadukan keduanya. Dalam hal ini ia memberi contoh beberapa sarjana yang berupaya membangun suatu teologi evolusioner. Yaitu suatu teologi baru yang dibangun berdasarkan teologi tradisional, tetapi sudah dibayangi pandangan dunia yang baru, di mana evolusi alam semesta maupun evolusi kehidupan di bumi menjadi salah satu penggeraknya. Contohnya, dalam pandangan dengan pendekatan konflik ini menganggap sains menyingkirkan Tuhan, sementara dalam pendekatan integrasi menganggap evolusi ini merupakan cara Tuhan menciptakan alam semesta beserta isinya (Bagir, 2006: 4-5).

Pandangan Barbour di atas kemudian disempurnakan oleh Michael Stenmark dalam How to Relate Sciene and Religion. Stenmark beranjak dari pemberian beberapa dimensi dalam sains dan agama, dan kemudian mengeksplorasi masing-masing dalam empat dimensi, yaitu a). Dimensi sosial sains dan agama, b). Tujuan sains dan agama, c). Epistemologi sains dan agama, dan d). Kandungan (content) teoritis sains dan agama. Dengan memperhatikan dan membandingkan kategori ini, Stemark sampai pada apa yang disebutnya "model multidimensi" hubungan sains dan agama.

Dengan model multidimensi Stenmark ini, tampaklah bahwa Barbour hanya terpaku pada dimensi keempat saja, yaitu pembahasan mengenai sains dan agama dengan fokus bagaimana agama (teologi) menanggapi teori-teori ilmiah baru. Demikian juga tampak bahwa Stenmark melampaui konteks sempit Kristen yang mengambil perhatian penuh pada pembahasan tentang evolusi. Dalam agama-agama lain, evolusi tidaklah merupakan isu yang penting meskipun bukan berarti tidak menimbulkan masalah. 
Dengan model Stenmark ini, terbuka ruang-ruang baru misalnya dengan dilakukannya perbandingan antara gagasan "sains Islam" ala Mehdi Golshani dengan sains teistik ala Alvin Plantinga ketika ia membahas dimensi-dimensi epistemologi sains dan agama (Bagir, 2006: 6).

Di kalangan muslim, menurut Ziuddin Sardar dalam Explorations in Islamic Science, ada beberapa tanggapan yang berkaitan dengan sains, yaitu 1). Upaya pencocokan ayat-ayat al Quran dengan temuan ilmiah, 2). Pandangan bahwa sains itu bersifat netral, dan karenanya yang diperlukan adalah nilainilai etika Islam untuk mengawal aplikasinya, 3). Penggagas sains sakral yang mengkritik keras sains modern seraya mengajukan alternatif pembangkitan kembali sains tradisional yang masih memiliki kandungan metafisis yang kuat, dan 4). Yang mengajukan landasan epistemologi islami untuk suatu sistem sains (Bagir, 2006: 7)

Sementara itu, pandangan terbaru untuk hubungan sains dan Islam disampaikan Ibrahim Kalin, seorang murid dari Sayyid Hossen Nasr dalam "Three views of Islamic Science". Menurut Kalin ada tiga kelompok pandangan mengenai Islam dan sains. Pertama, kelompok yang melihat sains terutama dalam dimensi etika sosialnya. Kelompok ini menekankan pentingnya penyerapan sains dan teknologi modern yang dianggap bebas nilai untuk kemajuan komunitas muslim, sembari melengkapimya dengan etika Islam. Kedua, kelompok yang melakukan kritik epistemologi sains modern yang dianggap memiliki keterbatasan metodologis yang akut sehingga tidak bisa mencapai kebenaran yang semestinya. Dan yang ketiga, kelompok yang berupaya setia pada metafisika tradisional dan melakukan kritik radikal atas metafisika sains modern. Dua kelompok yang terakhir ini melakukan kritik yang radikal terhadap sains modern dan mengajukan perlunya formulasi semacam sains Islam. Perbedaan antara keduanya menekankan pada epistemologi, berikut yang pertama, sedangkan yang kedua pada metafisika (Bagir, 2006: 8-9).

Jika direfleksikan sejenak mengenai relasi antara ilmu-ilmu agama dan ilmu-ilmu dunia modern, sebenarnya keduanya membicarakan hal yang sama, yaitu ayat-ayat Tuhan. Sebagaimana kita ketahui, ilmu-ilmu agama 
selalu mendasarkan dirinya pada kitab suci dan juga Hadits Nabi, bahkan juga aqwal sahabat. Pertama jelas sebagai ayat Tuhan, adapun yang kedua dan ketiga, pada taraf tertentu juga merupakan ayat Tuhan karena Nabi dan para sahabatnya adalah manusia istimewa yang mendapatkan petunjuk (Hadis Nabi). Sedangkan ilmu-ilmu modern yang dianggap non-agama pada dasarnya juga mengkaji ayat-ayat Tuhan. Hanya saja, yang pertama berdasarkan pada ayat-ayat yang bersifat tadwiniyah, sedangkan yang kedua lebih terfokus pada ayat-ayat kawniyah, realitas ilmiah atau fenomena alam. Dengan melihat kenyataan tersebut jelaslah bahwa kedua disiplin ilmu itu menempati posisi yang sederajat sebagai obyek ilmu. Demikian juga keduanya memiliki status ilmiah yang tidak berbeda. Hanya saja, untuk menilisik lebih jauh dalam pemahaman yang obyektif diperlukan alat atau sarana yang tentunya tidak sama antara keduanya. Ilmuwan ataupun masyarakat yang terlanjur ikut-ikutan membedakan status ilmiah kedua disiplin ilmu tersebut telah terjerumus dalam kekeliruan dan hal itu tidak boleh dibiarkan.

Selanjutnya, jika dikotomi itu dibiarkan berlanjut, maka akan muncul problem berupa kesenjangan mengenai sumber ilmu antara yang dianggap ilmu agama dan non-agama. Para pendukung ilmu agama hanya menganggap valid sumber-sumber ketuhanan yang berwujud kitab suci dan tradisi kenabian, dan mereka menolak sumber-sumber non-skriptural sebagai sumber yang memiliki otoritas untuk menjelaskan kebenaran atau ilmu. Bagi mereka, penalaran rasional dan pencerapan indera sering dinafikan sebagai sumber ilmu pengetahuan (Nasution, 1986: 83).

Pada pihak yang lain, para ilmuwan sekuler hanya menganggap valid informasi yang diperoleh melalui pengamatan inderawi saja, karena bagi mereka satu-satunya sumber pengetahuan adalah pengalaman empiris melalui pencerapan inderawi tersebut. Dalam hal ini, apa yang dicapai melalui penalaran atau akal rasional sering dicurigai sebagai apriori, karena akal bagi para pendukung metode ilmiah modern yang konvensional hanya sebagai alat bantu untuk memutuskan valid atau sah tidaknya pengamatan indera yang dilakukan, bukan sebagai sumber ilmu yang independen. Walaupun diakui bahwa pencapaian nalar yang tertinggi adalah filsafat,

Ulul Albab, Vol. 10, No. 1, 2009 
tetapi bagaimanapun ia tetap dipandang masih sangat spekulatif. Sebenarnya, filsafat dalam pemikiran para filosof Muslim mempunyai arti pencarian atau cinta terhadap kebenaran hakiki. Kebenaran hakiki itu hanya ada satu, tapi ia bisa muncul dalam berbagai wajah yang juga mengandung kehakikian (relatif tentunya) meskipun tidak persis sama. Karena itu, belajar filsafat tidak lain adalah belajar "meniru" yang "Hak". Dalam konteks tersebut filsafat adalah "hikmah" yang dari usaha mendapatkannya melahirkan kebijaksanaan. Jadi, berfilsafat sudah tentu tidak bisa meninggalkan akal dan hati (intuisi) secara bersamaan, di samping tentu saja pengamatan inderawi (Schimmel, 2000: 331-332).

Dalam khazanah pemikiran Islam tidak ada alasan menolak kehadiran sumber yang lain, yaitu intuisi atau hati. Intuisi ini menurut para ilmuwan sekuler tidak lain hanyalah halusinasi, bahkan hanya ilusi belaka. Padahal, intuisi bagi para penganut agama merupakan sumber pengetahuan (ma'rifah) yang sangat mulia. Dengannya para mistikus besar memperoleh limpahan cahaya dan dengannya pula Nabi menerima wahyu. Menolak intuisi sebagai sumber pengetahuan, dapat saja itu akan meruntuhkan pondasi utama kepercayaan manusia kepada kenabian. Dengan demikian, apabila integrasi ilmu agama dan non-agama diingkari, akan muncul suatu upaya saling membatalkan sumber-sumber berbeda yang dipakai oleh masing-masing kelompok di atas.

Pengingkaran terhadap integrasi kedua disiplin ilmu di atas juga akan berlanjut pada masalah yang berkenaan dengan obyek-obyek ilmu yang dianggap "sah" oleh masing-masingnya . Dalam discourse sains modern telah ditentukan bahwa objek-objek ilmu yang sah adalah segala sesuatu yang dapat diamati oleh indera (Kartanegara, 2002: 53). Maka sebaliknya, segala sesuatu yang berada di luar jangkauan yang dapat diamati, yaitu obyek-obyek nonfisik, dianggap tidak sah sebagai objek ilmu pengetahuan. Oleh karena itu, betapapun rasionalnya argumen yang dibangun oleh ilmu nonfisik ini, tetap saja tidak bisa mencapai status ilmiah seperti lazimnya ilmu. Pada pihak lain, para pendukung ilmu agama justru menganggap bahwa obyek-obyek non-fisik, yaitu metafisika atau pembahasan mengenai

Ulul Albab, Vol. 10, No. 1, 2009 
Tuhan, dunia kemalaikatan atau jiwa, merupakan kajian yang teramat mulia. Mempelajarinya akan meningkatkan status ilmiah bidang tersebut, di samping juga akan memberikan efek kebahagian tertentu bagi si pelaku (Khalid al Walid, tt: 172). Jadi, ia dapat dijadikan basis etis bagi ilmu pengetahuan yang tujuan utamanya adalah mencapai kebahagiaan.

Para ilmuwan Muslim percaya sepenuhnya dan sepakat bahwa sumber segala ilmu pengetahuan adalah Allah. Allah sebagai Tuhan dan Sebab Yang Pertama dalam istilah yang digunakan oleh para filosof Muslim disebut sebagai "Wajib al-Wujud" atau "The Ultimate Reality" (Realitas sejati). Adapun para Sufi menyebutNya dengan "Kebenaran Haqiqi" (al Haq). Kalau dimaklumi bahwa tujuan puncak dari ilmu adalah mengetahui realitas atau kebenaran seperti apa adanya, maka dengan demikian, al Haq sudah jelas menjadi sumber dari kebenaran lainnya, termasuk dalam hal ini kebenaran hasil observasi ilmu-ilmu non-agama atau ilmu alam. Sebuah ayat yang artinya "Kebenaran itu berasal dari Allah, maka janganlah sekali-kali engkau meragukannya" (QS. al Baqarah: 148 dan al Imran: 60), yang menjadi persoalan kemudian adalah bagaimana cara memperoleh kebenaran tersebut. Tentunya setiap kelompok, memiliki cara yang berbeda untuk mendapatkan kebenaran seperti yang didambakan.

Sudah maklumadanya kalau ahli agama mempunyai pemikiran bahwa sumber utama ilmu-ilmu keagamaan adalah kitab suci yang diturunkan kepada NabiNya. Dengan pemikiran ini, mereka kemudian berpandangan bahwa memahami ilmu Bahasa merupakan salah satu cara untuk memperoleh ilmu dari sumber yang tertulis dengan menggunakan bahasa tersebut. Dapat dimaklumi juga kalau ahli ilmu kealaman berpandangan bahwa alam semesta yang terhampar luas hingga galaksi-galaksi dan atomatom terkecil ini sebagai sumber ilmu. Untuk iru, pengamatan dan penelitian langsung bagi mereka merupakan cara memperoleh kebenaran. Berbeda dengan keduanya, para Sufi berlandaskan kepada otoritas wahyu dan juga pada kenabian atau mungkin "kewalian" berupa Imam-iman yang diyakini "maksum" memandang alam semesta beserta bagian-bagiannya. Hal ini merupakan maniféstasi sifat-sifat Allah, karenanya semua menjadi sumber 
ilmu dan dianggap "suci", dalam artian perlu dihormati dan diperlakukan sebagaimana mestinya.

Dengan melihat status ontologis dari masing-masing obyek pada disiplin keilmuan, baik dengan pengamatan indra, penjelasan logika yang rasional maupun dengan penyingkapan hizab pada hati seorang yang suci atau intuisi (Kertanegara, 2002: 60-61). Maka integrasi sains dan agama menjadi sesuatu yang patut dipahami dan direnungkan dalam-dalam. Dijelaskan bahwa ilmuwan Barat melupakan teori ketundukan yang mereka akui sendiri keberadaannya. Teori tersebut mengatakan bahwa alam fisik ini tidak mungkin menjadi sebab bagi dirinya sendiri. Ia senantiasa tunduk di bawah proses "kejadian" (generation) dan "kehancuran" (corruption). Itulah kenapa jauh sebelumnya para ilmuwan Muslim sudah menjelaskan bahwa alam ini membutuhkan agen lain yang "langgeng" sebagai "pencipta" dunia fisik ini.

Sebagai pencipta atau "sebab yang pertama" dalam istilah filsafat, status ontologisnya sudah tentu lebih bersifat fundamental daripada status ontologis akibat yang ditimbulkannya, yaitu alam fisik ini. Alam fisik ini sudah memiliki obyektivitas atau status ontologis yang nyata, maka status ontologis "sebab primernya" atau pencipta lebih nyata lagi. Tentu ia lebih sempurna dan lebih fundamental. Indikasi ketergantungan alam fisik pada sebab Yang Pertama ini dapat dilihat, misalnya dari sebutan yang diberikan Suhrawardi al Maqtul pada alam fisik ini sebagai al Fagir (yang membutuhkan), yaitu membutuhkan Dzat Yang Ghani, Yang berdiri sendiri dan tidak membutuhkan sesuatu yang lain untuk eksistensiNya (Schimmel, 2000: 331).

Dengan sedikit uraian di atas, tampak jelas bahwa pengamatan indera dan akal saja belum cukup untuk dapat menembus pada jantung realitas yang sebenarnya. Oleh karena itu masih dibutuhkan sarana atau metode lain yang dalam khazanah epistemologi Islam disebut intuisi atau irfani. Ciri khas dari metode ini adalah sifatnya yang langsung sehingga disebut pula dengan mukasyafah, yaitu penyingkapan langsung rahasia-rahasia dari realitas yang ada dengan bantuan Tuhan. Inilah sebenarnya yang direkomendasikan al 
Ghazali agar dicari dan tidak berpuas diri dengan pengamatan indera atau hasil analisa akal. Al Ghazalipun tidak menolak pengamatan inderawi, juga tidak menafikan hasil pengolahan akal, yang dinasihatkan olehnya adalah agar tidak merasa tercukupi hanya dengan kedua metode itu, apalagi dijadikan satu-satunya sumber. Bagaimana cara ini didapatkan, tentunya bukan dengan mempertajam pengamatan inderawi ataupun penajaman akal, melainkan dengan mengasah kepekaan hati, membersihkannya dari segala noda dan dosa. Metode ini mensyaratkan pelaku untuk merasakan objeknya secara langsung dan digambarkan dengan istilah dzawqi (rasa).

Bagi para filosof Muslim iluminasionis dan sufi, pengalaman mistik dengan metode merasakan langsung realitas-realitas obyek ini merupakan sarana yang paling efektif, karena sifatnya yang langsung dan intim dengan obyek. Pengetahuan model ini dalam khazanah keilmuan Islam disebut dengan ilmu hudhuri atau knowledge by presence (Schimmel, 2000: 54). Di sini, objek yang diteliti hadir dalam diri atau jiwa peneliti, sehingga terjadi kesatuan yang padu antara subjek dan objek. Sementara ilmu-ilmu lain yang disebut ilmu hushuli diperoleh melalui pengamatan inderawi terhadap objek-objek eksternal, karenanya, apa yang disimpulkan dari pengamatan semacam ini kadang berkorelasi positif, tapi terkadang juga tidak. Akibat darinya, ilmu hushuli ini tidak dapat menjamin kebenaran yang pasti karena adanya jurang menganga yang memisahkan antara subjek dan objek.

Status wujud dari objek-objek yang menjadi pengamatan para ilmuwan atau filosof ini berbeda-beda. Meskipun demikian, jika dilihat dalam doktrin wihdah al wujud, perbedaan itu hanya ada pada esensinya saja, dan pada hakikatnya adalah satu dan sama. Dalam hal ini, al. Farabi, Filosof Muslim yang disebut al Mu'allim al Tsani telah memberikan gambaran tentang hierarki wujud (martabat al maujudat) (Bakar, 1997: 118) sebagai berikut: 1). Tuhan, sebagai hierarki yang berada di puncak maujudat. Ia menjadi sebab dari keberadaan yang lain. 2). Para Malaikat yang berada satu level di bawahnya. Para malaikat ini murni sebagai wujud-wujud yang immaterial. 3). Benda-benda langit atau angkasa (celestial), dan 4). Benda-benda bumi (terrestrial)

Ulul Albab, Vol. 10, No. 1, 2009 
Tuhan, sebagai sebab dari keberadaan yang lain, tidak membutuhkan apapun, karena itu disebut "al Ghani". Sedangkan akibat, karenasifatnya yang tergantung kepada yang membawa kepada perwujudannya disebut dengan al Faqir. Untuk menerangkan pemikiran ini, para Filosof Muslim mencoba membuktikannya secara logis dan demonstratif. Ibnu Sina misalnya, ia menjelaskan bahwa keberadaan alam ini pada dasarnya hanyalah potensi (mumkin al wujud). Sebagai potensi, ia tidak bisa mengadakan dirinya sendiri, karena itu harus dicari agen yang bertanggung jawab atas keberadaannya tersebust. Agen yang dimaksud tidak lain adalah Tuhan, sebagai sebab Yang Pertama dari segala maujudat yang ada di alam raya ini (Kartanegara, 2002: 35). Seperti yang telah disinggung sebelumnya, status ontologis sebab, tentunya lebih fundamental dan esensial daripada status ontologis akibat, yaitu alam yang muncul dariNya.

Bagaimana tentang para Malaikat? Status ontologis para Malaikat sebagai makhluk yang menjadi "pembantu-pembantu" Tuhan merupakan wujud-wujud yang immaterial (mujarradah) juga. Berbeda dengan apa yang dikatakan dalam literatur keagamaan, bahwa para malaikat disebut sebagai pembantu Tuhan, dalam literatur filsafat (Islam), para malaikat jauh memiliki fungsi yang lebih krusial. Malaikat Jibril misalnya, ia dalam literatur filsafat dikatakan sebagai akal aktif yang di samping menjadi sumber pengetahuan juga bertugas memberi bentuk dunia material. Mengacu pada keterangan para filosof tersebut, maka dunia materiil yang ada saat ini tidak mungkin mewujud bila tidak diberi bentuk (shurah) oleh akal aktif, sekalipun ia telah memiliki unsur materiil, yaitu potensi murni. Dengan demikian, suatu benda baru akan berbentuk, dalam arti memiliki wujud kalau sudah ada perpaduan antara bentuk yang diberikan akal aktif dengan materi yang merupakan potensi murni (Kartanegara, 2005: 64).

Hierarki wujud yang ketiga, yaitu benda-benda langit seperti matahari, bintang-bintang, planet-planet, bulan dan benda-benda langit lainnya, dalam pandangan para filosof memiliki kedudukan, ciri dan sifat yang berbeda dengan benda-benda bumi. Dalam hal ini, Ibn Sina, al Farabi maupun Ibn Rusdi telah meyakini adanya jiwa-jiwa bintang atau planet sebagai 
benda-benda angkasa yang cukup mempunyai pengaruh terhadap bendabenda di bawahnya. Daya-daya yang dimiliki tumbuhan, hewan, dan juga manusia tidak bisa dipandang begitu saja sebagai sesuatu yang berasal dari diri mereka sendiri, melainkan sebagai pengaruh dari akal aktif, jiwa-jiwa planet dan benda-benda angkasa lain. Bercahayanya benda-benda angkasa merupakan petunjuk bahwa status ontologis mereka lebih tinggi daripada bumi, termasuk hal-hal yang muncul darinya, yaitu objek-objek fisik yang bisa diamati dengan mata.

Matahari misalnya, ia dapat menumbuhkan tumbuh-tumbuhan. Dari tumbuhan itu, hidup dan berkembanglah hewan-hewan dan manusia. Jadi, status matahari yang sudah terbukti menjadi sumber tenaga dan kehidupan di bumi ini tentu lebih tinggi daripadanya. Itulah sebabnya kenapa Ibn Sina percaya bahwa matahari memiliki jiwa. Hampir sependapat dengan Avicena (Ibn Sina), Averroes (ibn Rusydi) mengatakan bahwa sinar matảhari merupakan sumber dari kehidupan dan panas alami (natural heat), dan panas alami tersebut merupakan sebab dari daya nutrisi yang menjadi daya primer seluruh makhluk hidup (Fakhry, 2001: 52). Sekali lagi ini menegaskan bahwa status ontologis benda-benda langit lebih tinggi daripada bendabenda bumi.

Untuk yang keempat, yaitu benda-benda bumi (terrestrial). Mungkin tidak perlu berargumen tentang statusnya, karena semua ilmuwan mengakuinya, termasuk ilmuwan Barat. Dengan demikian jelaslah bahwa sesuai dengan prinsip kesatuan wujud, tingkat-tingkat wujud mulai yang metafisik hingga yang fisik, mulai yang nyata namun ghaib dan samar sampai yang berwujud benda yang bisa dilihat tanpa alat, oleh para filosof Muslim diakui status ontologisnya, dan semua itu sah-sah saja dijadikan sebagai obyek ilmu, dengan cara dan epistemologi yang berbeda pula tentunya.

Meminjam doktrin dan prinsip yang dipahami kaum sufi, wahdah al wrijud, maka wujud-wujud yang mengisi rangkaian atau hirarki wujud ini merupakan satu kesatuan yang tidak bisa dipisah-pisahkan satu sama lain atau diperlakukan sesuai kehendak sendiri yang pilih kasih. Dengan prinsip wahdah wujud tersebut, objek-objek ilmu itu harus dipandang sebagai 
kesatuan yang terpadu dan diperlakukan sama, disajikan secara utuh, bukan sepotong-sepotong.

Memang sains modern telah agak lama menyingkirkan pertanyaan penting dalam penjelasan ilmiahnya, yaitu pertanyaan "Untuk apa sesuatu (alam) itu ada atau diadakan?". Sedangkan dalam khazanah pemikiran Islam setidaknya ada beberapa jawaban untuk pertanyaan tersebut, di antaranya dikatakan bahwa alam ini diciptakan bil hag, dengan tujuan tertentu, bukan kebetulan. Alam diciptakan bukan hanya untuk menunjukkan keberadaanNya namun juga kebesaran, kebijaksanaan dan kasih sayangNya. Bahkan dalam doktrin sufi di atas, alam semesta ini adalah manifestasi (tajalli) sifat-sifat Ilahi. Dengan demikian, melalui manifestasinya manusia semestinya mampu mengenal dan selanjutnya mencintai Tuhannya. كنت كنزا مخفيا فاحببت أن أعرف فخلف - الحلق" Sebagaimana Hadits Qudsy Aku adalah harta yang terpendam, Aku cinta untuk dikenal, maka Aku ciptakan alam semesta dan mereka kemudian mengenalKu. Kalau di hadapan kita ada kursi, sains hanya mampu menjelaskan ia berasal dari kayu yang dibentuk si tukang hingga menjadi kursi, bahkan kenapa si tukang membentuknya menjadi kursipun sains tak mampu memahami. Sedangkan pemikiran keislaman yang dipadu dengan intuisi (filsafat), jauh ke asal di mana kayu ditanam dan kenapa ditanam.

Akhirnya harus diakui bahwa semua obyek yang kini menjadi kebanggaan sains modern seperti air, udara hingga benda-benda mineral, batu-batuan dan logam-logaman sampai benda-langit yang tampak mata (telanjang atau dengan alat) itu adalah bagian yang integral dari obyek-obyek lainnya, yang membentang mulai dari Tuhan yang berada di puncak hierarki wujud hingga yang paling kentara di depan mata kita. Dalam sebuah sistem yang integral itu, kurang adil rasanya bila di antara yang maujud itu ada satu jenis obyek yang ditinggalkan. Kalau dipaksakan untuk bersikap demikian, maka sudah pasti akan menyisakan ketimpangan tertentu yang pada gilirannya melahirkan sains yang lumpu atau juga agama yang membabi buta.

Ulul Albab, Vol. 10, No. 1, 2009 


\title{
Simpulan
}

Pasca Renaissance, para ilmuwan Barat merasa ragu atau bahkan meyakini tidak adanya realitas metafisik (alam ghaib) pada fenomena yang mereka lihat dan mereka amati. Konsekuensi iman ini membawa kepada keimanan lain yang menyimpang berupa kepenganutan pada paham sekuler dalam berbagai bentuknya, seperti agnotisisme, naturalisme, materialisme, positivisme, atau bahkan ateisme. Oleh karena itu, tidak mengherankan jika dikatakan bahwa di Barat telah terjadi sekularisasi ilmu, di mana pembicaraan mengenai science hanya dibatasi pada entitasentitas fisik semata. Seiring dengan hegemoni Barat, pandangan ini diadopsi di mana-mana dan tidak ketinggalan di tanah air kita. Dalam model sains yang demikian, hati nurani terlepas dari akal sehat, nafsu serakah menguasai perilaku para cerdik pandai, praktik-praktik kotor seperti korupsi, kolusi dan sikap-sikap kotor lainnya merajalela, hingga "jagad raya" rusak berat.

Basis sains modern yang dibatasi pada realitas fisik ini didorong oleh dugaan objektivitas (positivisme) yang terkandung di dalamnya. Itu pula yang dijadikan alasan penganutnya menolak epistemologi Islam.yang di samping menganjurkan penerapan pengamatan inderawi juga pemanfaatan optimal logika dan intuisi yang berbasis di hati atau perasaan. Bagi para positivist, logika dan terutama intuisi bersifat subyektif, karena itu tidak bisa dijadikan landasan keilmiahan yang memang mensyaratkan obyektivitas. Padahal, pada hakikatnya, semua pengamatan tidak terkecuali yang inderawi, dengan penggunaan alat sekalipun masih tetap mengandung unsur subyektivitas. Tingkat subyektivitasnya paling tidak terletak pada keterbatasannya yang tidak mampu menangkap semua realitas. Penglihatan misalnya, tidak bisa menangkap semua rangkaian gelombang cahaya kecuali sebatas frekuensi antara 400-700 nanometer. $\mathrm{Di}$ atas atau di bawah frekuensi tersebut tidak akan mampu dipersepsikan secara visual. Demikian juga pendengaran, ia tidak mampu menangkap gelombang suara di atas atau di bawah 20-20.000 kilo hertz/detik (Kartanegara, 2003: 53). Oleh karena itu, jelaslah bahwa indera juga terbatas jangkauannya.

Untuk menutup kekurangan persepsi indera ini, diciptakanlah akal

\author{
Ulul Albab, Vol. 10, No. 1, 2009
}


atau logika yang dengannya mampu ditangkap objek-objek dalam rentangan yang lebih luas, bahkan mungkin tak-terbatas. Meskipun demikian, jangan jumawa ternyata keluasan jangkauan akal tersebut masih berputar pada persoalan kulit luar dari realitas non-fisik. Untuk menyelami hingga masuk ke jantung realitas dibutuhkan pengala man supraintelek yang disebut mistik, "Jangan hanya tahu nama, kenali Yang Punya Nama," kata Rumi. Inilah yang dialami oleh para wali pada tingkatan paling tinggi dan menjadi sesuatu yang lumrah pada diri para Nabi. Agar tidak terjadi distorsi yang sangat serius terhadap gambaran realitas yang sebenarnya utuh, pengalaman mistik yang berpuncak pada nubuwwah atau impen kaweruh bagi orang saleh kebanyakan tidak boleh ditinggalkan. Dengan demikian, jelaslah bahwa indera bukanlah satu-satunya sumber untuk mengungkap realitas yang teramat luas, tapi butuh akal dan setelah itu, masih butuh yang lain, hati yang suci atau intuisi.

Dengan demikian, akhir dari sebuah pencarian, dengan menggunakan sarana apa saja sudah tentu adalah bertemunya dengan sesuatu yang dicari. Sains menemukan kebenaran ilmiah, agama menemukan hakikat dari yang tampak sebagai kenyataan, keduanya akan membawa kepuasan tertentu yang berimbas pada kebahagiaan, bukan hanya bagi pelakunya, tapi juga pihakpihak lain, bahkan juga bagi yang tidak peduli. Kalau penemuan itu tidak berpuncak pada kebahagiaan, berarti ada yang keliru. Kekeliruan bukan pada realitasnya, karena hal itu memang sudah given atau realitas yang tidak bisa ditolak, tetapi pada cara memahami atau menafsirkannya. 


\section{Daftar Pustaka}

Agus, Bustanuddin. 2007. Agama dalam Kehidupan Manusia. Jakarta: Raja Grafindo Persada.

Bagir, Zainal Abidin dkk, 2006. Ilmu, Etika dan Agama Menyingkap Tabir Alam dan Manusia. Jogjakarta: CRCS.

Bakar, Osman. 1997. Hierarki Ilmu: Membangun Rangka-Pikir Islamisasi llmu. Bandung: Mizan.

Campbell, Joseph. 1988. The Power of Myth. New York: Doubleday.

Fakhry, Majid. 2001. Averroes. Oxford: Oneworld.

Iqbal, M. 1981. The Reconstruction of Religious Thought in Islam. New Delhi: Kitab Bhavan.

Kartanegara, Mulyadhi. 2002. Menembus Batas Waktu: Panorama Filsafat Islam. Bandung: Mizan.

2005. Integrasi Ilmu Sebuah Rekonstruksi Holistik. UIN Jakarta Press.

. 2003. Menyibak Tirai Kejahilan: Pengantar Epistemologi Islam. Bndung: Mizan.

al-Walid, Khalid. Tt. Tasaunf Mulla Shadra: Konsep Ittihad al-Aqil wa al-Ma'qul dalam Epistemologi Filsafat Islam dan Makrifat Ilahiyah. Bandung: Muthahhari Press.

Muchtar, A. 2001. Tunduk Kepada Allah: Fungsi dan Peran Agama dalam Kehidupan Manusia. Jakarta: Khazanah Baru.

Muthahhari, Murtadha. 2007. Manusia dan Agama Membumikan Kitab Suci. Bandung: Mizan.

Nasution, Harun. 1986. Teologi Islam: Aliran-aliran, Sejarah dan Analisa Perbandingan. Jakarta: UI Press.

Pals, Daniel L. 1996. Seven Theories of Religion. New York: Oxford University Press.

Ulul Albab, Vol. 10, No. 1, 2009 
Rahmat, Jalaluddin. 2005. Psikologi Agama. Bandung: Mizan.

Schimmel, Annemarie. 2000. Dimensi Mistik Dalam Islam. Terjemahan oleh Sapardi Djoko Damono dkk. Jakarta: Pustaka Firdaus.

Shihab, M. Quraish. 1996. Wawasan al Quran. Bandung: Mizan.

Rahmad, Jalaluddin. 2005. Psikologi Agama. Bandung: Mizan. 